\title{
A case of Glanzmann thrombasthenia presenting at birth
}

\author{
K D S K Savithri ${ }^{1}$, A M B W M R N N Ekneligoda ${ }^{1}$, A Y Wimalasiri ${ }^{1}$, H D K S K Thilakarathna ${ }^{1}$, \\ *M Weerasekera ${ }^{2}$
}

Sri Lanka Journal of Child Health, 2020; 49(1): 83-84

DOI: http://dx.doi.org/10.4038/sljch.v49i1.8907

(Key words: Glanzmann thrombasthenia, newborn)

\section{Introduction}

Glanzmann thrombasthenia (GT) is a rare (1 in $1,000,000)$ platelet functional disorder with an autosomal recessive inheritance ${ }^{1-4}$. It is characterized by a defect in platelet receptor GPIIb/IIIa $a^{1,2,4}$. This leads to absent or reduced clot retraction and absent platelet aggregation with physiological agents. Patients generally present with muco-cutaneous bleeding which can be fatal ${ }^{1}$. Although the onset of symptoms occurs in infancy or early childhood, these patients are usually diagnosed later in early childhood, before the age of 5 years due to recurring episodes of epistaxis and gum bleeding ${ }^{4}$. In the literature, the youngest case reported to-date is an Indian baby presenting at six days of age $\mathrm{e}^{3,4}$. So far, in Sri Lanka only a single paediatric case report has been published ${ }^{2}$. We report a case of GT presenting at birth.

\section{Case report}

A non-asphyxiated baby girl born via nonprecipitous vaginal delivery at 35 weeks of gestation with a birth weight of $3.23 \mathrm{~kg}$ was noted to have a generalized, widespread petechial rash soon after birth. She manifested coffee ground nasogastric aspirates after admission to the special care baby unit on day 1 of age. The antenatal period was uncomplicated and the mother was not on any antiepileptic, anti-tuberculous or anti-coagulant drugs. She was the first child born to non-consanguineous parents. Mother gives a history of increased bleeding tendency with minor trauma, but she does not give a history of excessive bruising or menorrhagia. There is no documented family history for any haematological disease.

${ }^{1}$ Registrar in Paediatrics, ${ }^{2}$ Consultant
Neonatologist, Sri Jayawardenepura General
Hospital, Nugegoda, Sri Lanka
${ }^{* C o r r e s p o n d e n c e: ~}$ medhaweerasekera@gmail.com

(iD) https://orcid.org/0000-0001-5065-1889

(Received on 10 June 2018: Accepted after revision on 20 July 2018)

The authors declare that there are no conflicts of interest

Personal funding was used for the project.

Open Access Article published under the Commons Attribution CC-BY (c) (i) License

On examination, the baby was active, afebrile and not pale. There was a generalized petechial rash and a few ecchymotic patches (Figure1).

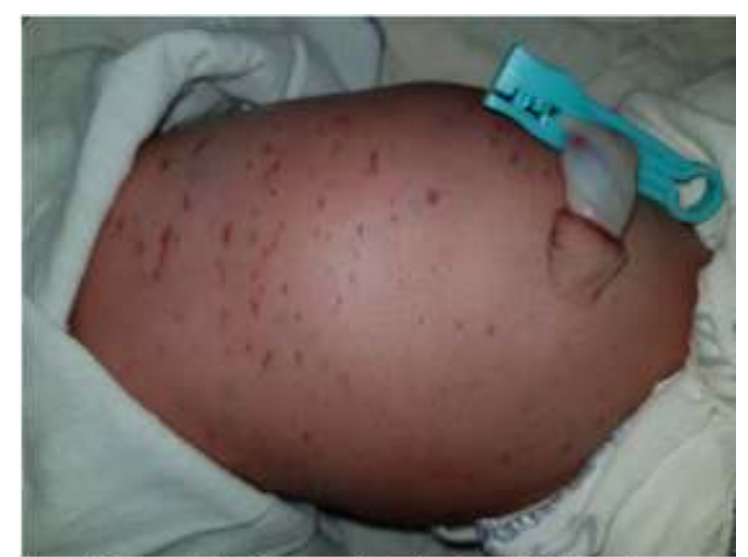

Figure 1: Generalised petechial rash

There were no other bleeding manifestations. She did not have any dysmorphic features and the red reflex was present. She was moving all four limbs and had normal tone. The occipito-frontal circumference was $34 \mathrm{~cm}$ and the anterior fontanelle was normal. There was no hepatosplenomegaly. Rest of the neonatal examination was normal.

Her initial work-up revealed normal platelet counts $\left(226,000 / \mathrm{mm}^{3}\right)$ which were normal throughout. Haemoglobin level was $19 \mathrm{mg} / \mathrm{dl}$. Blood picture showed adequate platelets with normal morphology. There were no atypical cells and other cell lines were normal. Septic screening was negative. Clotting profile [prothrombin time (PT), activated partial thromboplastin time (APTT), and thrombin time (TT)) was normal throughout. Although the bleeding time was not done initially, the test performed at one-and-a-half months of age, was prolonged ( $>15$ minutes). Ultrasound scan of the brain did not reveal intracranial bleeding.

She was managed on day 01 with transfusion of fresh frozen plasma and an additional dose of intravenous vitamin $\mathrm{K}$ as preventive measures for possible life-threatening bleeding. She did not require any platelet transfusions. The rash disappeared by day 8 . However, she had 3 episodes of blood stained stools on day 11 which settled spontaneously. At one-and-a-half months of age she 
presented with a febrile illness with the reappearance of generalized petechial rash. Platelet function test using light transmission aggregometry (LTA) performed on day 05 of age revealed absent aggregation response to adenosine-5'-diphosphate (both high and low doses) and arachidonic acid with a minimum response to collagen and a primary response to ristocetin. This was reconfirmed at oneand-a-half months of age. A diagnosis of Glanzmann thrombasthenia was made on LTA results.

\section{Discussion}

Glanzmann thrombasthenia (GT) manifests with muco-cutaneous bleeding of varying severity ranging from skin bleeds to fatal haemorrhage. Purpura, epistaxis, gingival haemorrhage, and menorrhagia are common presentations; gastrointestinal bleeding and haematuria are less common ${ }^{1,3,4}$. First symptoms usually appear during early infancy to early childhood. However, cutaneous manifestations can occur shortly after birth especially in vaginal deliveries ${ }^{1}$. Since the condition shares common clinical and laboratory features with other acquired platelet disorders, the diagnosis has been often overlooked.

Investigations such as complete blood count, PT, APTT will be entirely normal with a prolonged bleeding time warranting further investigation ${ }^{1,4}$. LTA is a diagnostic tool in assessing platelet function which is highly specific for $\mathrm{GT}^{4}$. However, in paediatric patients, it is difficult to obtain a platelet rich plasma which warrants repeated studies. Deficiency of GPIIb / IIIa receptor is confirmed by flow cytometry ${ }^{4,5}$.

It is recommended that all patients with GT be followed up by a haematologist. These patients do not need therapy on a regular basis but should be made aware of actions that need to be taken during a bleeding episode ${ }^{4}$. The importance of avoiding contact sports and non-steroidal anti-inflammatory drugs (NSAIDs) along with maintenance of good oral hygiene should be stressed to parents. Female patients should be monitored for iron deficiency anaemia on a regular basis after the onset of menarche. Parents and patients should be educated on the measures to be taken during minor bleeding episodes such as applying pressure, use of oral antifibrinolytics and to seek medical advice if bleeding persists. Since these patients might need platelet transfusions at some point, HLA typing should be performed and where possible HLA matched platelets should be transfused to avoid development of anti-platelet antibodies. Ideally, both parents should be screened for carrier detection. With proper supportive care, GT has an excellent prognosis ${ }^{4}$. Therefore, it should be considered in evaluating a patient with a bleeding disorder at any age.

\section{References}

1. Jpau Scot, Congenital abnormalities of platelet function. In: Kliegman RM, Stanton BMD, St. Geme J, Schor NF, editors. Nelson Textbook of Pediatrics $20^{\text {th }}$ edition. Elsevier; 2016. p.2407.

PMCid: PMC4984058

2. Morawakkorala RN, Senarathna AMRD, de Alwis ACD, Rathnamala V. Glanzmann thrombasthenia - presenting as prolonged severe bleeding following minor trauma. Sri Lanka Journal of Child Health 2006; 35:36-7.

https://doi.org/10.4038/sljch.v35i1.8

3. Swathi J, Gowrishankar A, Jayakumar SA, Jain K. A rare case of bleeding disorder: Glanzmann's thrombasthenia. Annals of African Medicine 2017; 16(4):196-198. https://doi.org/10.4103/aam.aam_59_16 PMid: 29063905 PMCid: PMC5 $\overline{6} 7 \overline{4} 411$

4. Solh T, Botsford A, Sollh M. Glanzmann's thrombasthenia: pathogenesis, diagnosis and current and emerging treatment options. Journal of Blood Medicine 2015; 6: 219-27. https://doi.org/10.2147/JBM.S71319 PMid: 26185478 PMCid: PMC4501245

5. Sebastiano C, Bromberg M, Breen K, Hurford MT. Glanzmann's thrombasthenia: Report of a case and review of the literature. International Journal of Clinical and Experimental Pathology 2010; 3(4): 443-7. PMid: 20490335 PMCid: PMC2872751 